\title{
Spatial/Temporal Characterization and Risk Assessment of Trace Metals in Mangla Reservoir, Pakistan
}

\author{
Muhammad Saleem, ${ }^{1}$ Javed Iqbal, ${ }^{1}$ Gulraiz Akhter, ${ }^{2}$ and Munir H. Shah ${ }^{1}$ \\ ${ }^{1}$ Department of Chemistry, Quaid-i-Azam University, Islamabad 45320, Pakistan \\ ${ }^{2}$ Department of Earth Sciences, Quaid-i-Azam University, Islamabad 45320, Pakistan \\ Correspondence should be addressed to Munir H. Shah; mhshahg@qau.edu.pk
}

Received 5 January 2015; Revised 23 June 2015; Accepted 28 July 2015

Academic Editor: Samuel B. Dampare

Copyright (C) 2015 Muhammad Saleem et al. This is an open access article distributed under the Creative Commons Attribution License, which permits unrestricted use, distribution, and reproduction in any medium, provided the original work is properly cited.

Composite water samples were collected from different sites of Mangla reservoir, Pakistan, in premonsoon, monsoon, and postmonsoon seasons. The physicochemical parameters and trace/heavy metals were determined in all water samples. The results manifested significant seasonal variations among $\mathrm{Co}, \mathrm{Cr}, \mathrm{Ni}$, and $\mathrm{Pb}$ and the metals exhibited highest contribution in premonsoon season except Mn. Principal component analysis (PCA) and cluster analysis (CA) revealed considerable anthropogenic intrusions in the reservoir. Probable risk associated with the metals levels on human health was also evaluated using hazard quotients (HQ) by ingestion and dermal routes for adults and children. It was noted that $\mathrm{Cd}, \mathrm{Co}, \mathrm{Cr}, \mathrm{Ni}$, and $\mathrm{Pb}\left(\mathrm{HQ}_{\mathrm{ing}}>1\right)$ were the most important pollutants leading to noncarcinogenic concerns. The $\mathrm{HQ}_{\text {derm }}$ levels of all metals were below unity, suggesting that these metals posed no hazards via dermal absorption, while the oral intake was the major exposure pathway. The largest contributors to chronic risks were $\mathrm{Cd}, \mathrm{Co}, \mathrm{Cr}, \mathrm{Ni}$, and $\mathrm{Pb}$ in all the seasons. Therefore, immediate measures should be taken for sustaining the healthy aquatic ecosystem

\section{Introduction}

Lakes are important and significant bodies in preserving freshwater, replenishing underground water, and adjusting local climate; consequently, they are considered one of the most versatile ecosystems in the world [1-3]. Recently, with the increasing urbanization and exhaustive development of industry, trace metals pollution in the lakes has become a worldwide problem because they are nondegradable and most of them have toxic effects on the organisms [4]. The accumulation of metals in aquatic ecosystems can lead to hazards on human and wildlife; therefore, researchers have been focusing on quantifying trace metals and their risk assessments on the aquatic environment [4-9]. Metals are derived from a variety of natural and anthropogenic sources, such as atmospheric deposition, geological weathering of rocks, untreated municipal wastes and industrial effluents, mining and mineral processing, electroplating, metal chelates from different industries, and agricultural activities mainly due to indiscriminate use of fertilizer [7, 10-18]. Multivariate statistical techniques are powerful tools for meaningful data reduction and the interpretation of geochemical data; hence, they are widely used in geochemical and ecochemical studies $[6,19,20]$. These methods have been frequently applied to identify pollution sources, to apportion natural versus anthropic contributions, and to describe the spatial distribution of pollutants [18, 21-25].

The Mangla Lake (Mirpur, Pakistan) was erected for hydroelectric power generation, irrigation, and flood control in 1967 across Jhelum River. Currently, the Lake water is also used for drinking and household purposes in adjoining areas. In this respect, the concentrations of trace metals in the Lake in different seasons were of great concern. The objectives of this study were (1) to quantify the dissolved concentrations of cadmium (Cd), cobalt (Co), chromium (Cr), copper $(\mathrm{Cu})$, iron $(\mathrm{Fe})$, manganese $(\mathrm{Mn})$, nickel $(\mathrm{Ni})$, lead $(\mathrm{Pb})$, and zinc $(\mathrm{Zn})$ in the Lake in premonsoon, monsoon, and postmonsoon seasons, (2) to determine the spatial and temporal 


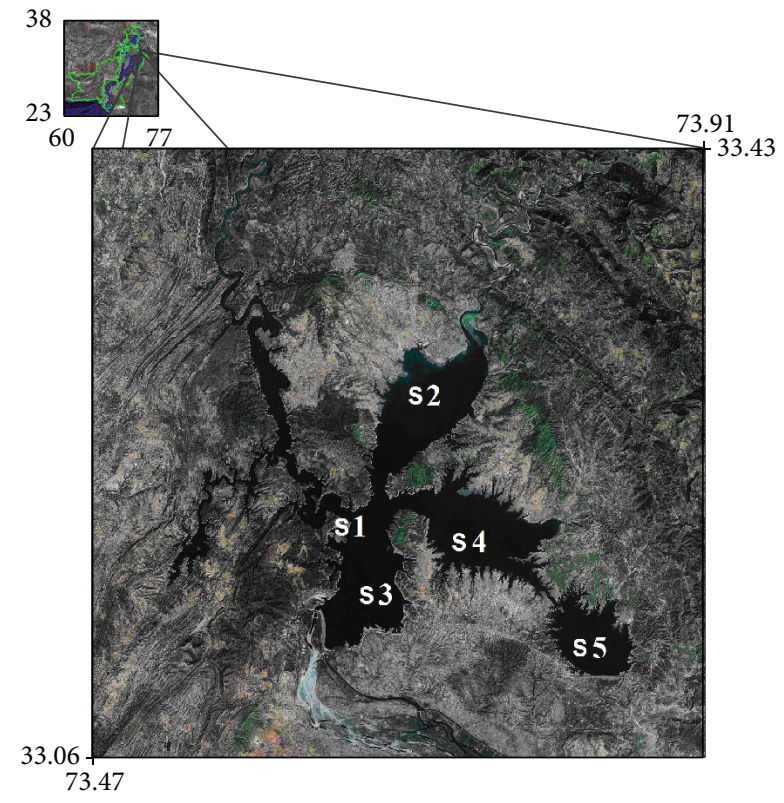

FIGURE 1: Map of the study area showing sampling sites.

variations of the metals in the Lake, (3) to evaluate water quality by comparing the measured levels with guidelines for drinking water and the protection of freshwater aquatic life, (4) to compare their concentrations with national and international reported levels, (5) to explore the natural and/or anthropogenic sources of these metals in the reservoir, and (6) to assess the human health risk associated with the metal levels. Ultimately, the study would help to develop water management and conservation strategies for the reservoir.

\section{Materials and Methods}

2.1. Study Area. Mangla reservoir is one of the largest freshwater resources in Pakistan (Figure 1). It was impounded in 1967 by damming Jhelum River near Mirpur city, Azad Jammu, and Kashmir, Pakistan. The reservoir is fed by two perennial rivers (Jhelum and Poonch) and two nonperennial rivers (Kanshi and Khad). It has five reservoir pockets: Jhelum, Poonch, Main Mangla, Khud, and Jari. The main dam is $3140 \mathrm{~m}$ long and $138 \mathrm{~m}$ high (above core trench) with a reservoir of $253 \mathrm{~km}^{2}$. Since its construction, the water storage capacity of Mangla Dam has been reduced from 7,255 to 5,764 million cubic meters due to high sedimentation rates from the catchments areas [26]. The contribution of the Lake related to betterment of environment such as farming progression, employment, and enhanced living standard is noteworthy. Furthermore, provision of extra water and power production enlarges these encouraging influences. The Lake water is also being used for drinking purpose by the inhabitants. The untreated municipal and poultry wastes, industrial effluents, and agricultural runoffs from the villages, towns, and city around the reservoir are the major pollution sources for the Lake water. In addition, various streams also carry the pollutants into the reservoirs during the high flow period.
TABLE 1: Certified versus measured concentrations $(\mu \mathrm{g} / \mathrm{L})$ of trace metals in standard reference material (SRM 1643d).

\begin{tabular}{lcc}
\hline Metal & Certified concentration & Measured concentration \\
\hline $\mathrm{Cd}$ & $6.47 \pm 0.37$ & $6.09 \pm 0.28$ \\
$\mathrm{Cr}$ & $18.53 \pm 0.20$ & $19.7 \pm 0.24$ \\
$\mathrm{Co}$ & $25.00 \pm 0.59$ & $22.3 \pm 0.41$ \\
$\mathrm{Cu}$ & $20.5 \pm 3.8$ & $19.2 \pm 2.1$ \\
$\mathrm{Fe}$ & $91.2 \pm 3.9$ & $92.6 \pm 3.5$ \\
$\mathrm{Mn}$ & $37.66 \pm 0.83$ & $36.1 \pm 0.67$ \\
$\mathrm{Ni}$ & $58.1 \pm 2.7$ & $61.2 \pm 2.1$ \\
$\mathrm{~Pb}$ & $18.15 \pm 0.64$ & $19.7 \pm 0.83$ \\
$\mathrm{Zn}$ & $72.48 \pm 0.65$ & $69.6 \pm 0.94$ \\
\hline
\end{tabular}

2.2. Sampling, Processing, and Analysis. Composite water samples were collected from five sites in the Lake (as shown in Figure 1) in premonsoon (May 2012), monsoon (August 2012), and postmonsoon (November 2012). Direct method was employed to collect the water samples (triplicate) in polyethylene bottles (1.5 L, volume capacity) following standard procedure [27]. Each water sample was composed of three equal volume subsamples from an area of $10-20 \mathrm{~m}^{2}$. The samples were kept in airtight large plastic ice-cold containers and were transported to laboratory within $6 \mathrm{~h}$ of their collection for further processing. Suspensions in the water samples were removed through filtration. The initial portion of filtration was discarded and the next one was preserved in refrigerator after acidifying with $\mathrm{HNO}_{3}(\mathrm{pH}<2)$ until chemical analysis $[4,28]$.

The water quality parameters including temperature (T), hydrogen ion concentration $(\mathrm{pH})$, dissolved oxygen (DO), and total dissolved solids (TDS) were measured in the field/on site: $\mathrm{pH}$ was measured using a digital $\mathrm{pH}$ meter (model: Martini Mi 180); DO was estimated by digital DO meter (model: Martini Mi 190); TDS were measured by a digital TDS meter (model: Jenway 470). Concentrations of the metals $(\mathrm{Cd}, \mathrm{Cr}, \mathrm{Co}, \mathrm{Cu}, \mathrm{Fe}, \mathrm{Mn}, \mathrm{Ni}, \mathrm{Pd}$, and $\mathrm{Zn}$ ) were determined using a flame atomic absorption spectrophotometer (model: Shimadzu AA-670, Japan). Calibration line method was used for the quantification of metals. A reagent blank was analyzed to determine the contamination during processing/preserving of the water samples. All the measurements were made in triplicate. The reliability of the analytical data was ensured by using standard reference material (SRM$1643 \mathrm{~d}$ ) and the results are shown in Table 1. Instrument settings were as recommended in the manufacturer's manual, with wavelengths ( $\mathrm{nm}$ ) of $228.8(\mathrm{Cd}), 240.7$ (Co), $357.9(\mathrm{Cr})$, $324.8(\mathrm{Cu}), 248.3(\mathrm{Fe}), 279.5(\mathrm{Mn}), 232.0(\mathrm{Ni}), 217.0(\mathrm{~Pb})$, and $213.9(\mathrm{Zn})$.

Chemical reagents (AR grade, certified purity > 99.99\%) used during chemical processing and analysis were purchased from E-Merck (Darmstadt, Germany). Doubly distilled water was used for the preparation of working standards from stock solution $(1000 \mathrm{mg} / \mathrm{L})$ and for the dilution of water samples whenever required [29]. Glassware was decontaminated by washing with tap water and detergent solution $(5 \%, \mathrm{w} / \mathrm{v})$, soaked in nitric acid (5\%,v/v) overnight, and rinsed with 
doubly distilled water, respectively. If some adhering organic matter was suspected, a rinse with acetone followed by doubly distilled water was also given. Finally, the glassware was dried in an oven maintained at $85^{\circ} \mathrm{C}$ for more than six hours prior to use.

2.3. Statistical Analyses. Possible sources of the metals in water reservoir were identified by principal component analysis (PCA) and cluster analysis (CA). PCA was applied on the dataset after varimax normalized rotation. It yielded significant principal components (PCs) which showed the contribution of major sources to total pollution index [2932]. Cluster analysis (CA), an unsupervised configuration recognition method, disposed a set of variables into two or more jointly unidentified clusters established on grouping of internal variables. Its purpose was to ascertain a scheme of unifying variables where each cluster shared communal properties. Ward's method was applied to obtain dendrogram of CA showing grouping of the metals and sampling sites to assess the spatial variability [4]. Statistical analyses were carried out using STATISTICA software [33].

2.4. Human Health Risk Assessment. Human beings are exposed to trace metals through three possible ways: direct ingestion, inhalation, and dermal contact. Oral intake and dermal absorption routes are most common for drinking water [34-37]. The average daily doses through these pathways can be determined using the following equations:

$$
\begin{aligned}
\mathrm{ADD}_{\text {ing }} & =\frac{C_{\text {water }} \times \mathrm{IR} \times \mathrm{EF} \times \mathrm{ED}}{\mathrm{BW} \times \mathrm{AT}}, \\
\mathrm{ADD}_{\text {derm }} & =\frac{C_{\text {water }} \times \mathrm{SA} \times K_{p} \times \mathrm{ET} \times \mathrm{EF} \times \mathrm{ED} \times \mathrm{CF}}{\mathrm{BW} \times \mathrm{AT}},
\end{aligned}
$$

where $\mathrm{ADD}_{\text {ing }}$ is the average daily dose by ingestion $(\mu \mathrm{g} / \mathrm{kg}$ day), $\mathrm{ADD}_{\text {derm }}$ is the average daily dose through dermal absorption $\left(\mu \mathrm{g} / \mathrm{kg}\right.$-day), $C_{\text {water }}$ is the mean metals concentration in surface water $(\mu \mathrm{g} / \mathrm{L})$, IR is the ingestion rate (L/day, 2.2 for adults and 1.8 for children), EF is the exposure frequency (days/year, 350), ED is the exposure duration (years, 70 for adults and 6 for children), BW is the average body weight (kg, 70 for adults and 15 for children), AT is the averaging time (days, 25550 for adults and 2190 for children), SA is the exposed skin area $\left(\mathrm{cm}^{2}, 18000\right.$ for adults and 6600 for children), ET is the exposure time (hours/day, 0.58 for adults and 1 for children), $C F$ is the unit conversion factor $\left(L / \mathrm{cm}^{3}\right.$, $0.001)$, and $K_{p}$ is the dermal permeability coefficient $(\mathrm{cm} / \mathrm{h})$, 0.001 for $\mathrm{Cd}, \mathrm{Cu}, \mathrm{Fe}$, and $\mathrm{Mn}, 0.002$ for $\mathrm{Cr}, 0.004$ for $\mathrm{Co}, \mathrm{Pb}$, and $\mathrm{Ni}$, and 0.0006 for $\mathrm{Zn}[12,35-39]$.

Risk evaluation related to the noncarcinogenic risks was quantified by computing hazard quotient (HQ). The HQ is a ratio of average intake of contaminants from exposure ways (oral intake/dermal) to the related reference dose (RfD) which was calculated using the following equation:

$$
\mathrm{HQ}_{\text {ing/derm }}=\frac{\mathrm{ADD}_{\text {ing/derm }}}{\mathrm{RfD}_{\text {ing/derm }}} .
$$

Significant noncarcinogenic risk is associated with HQ > 1. Hazard index (HI) was computed to determine the total possible noncarcinogenic risks posed by multipathways. The HI was computed by adding the HQs from all probable pathways as below:

$$
\mathrm{HI}_{\text {ing/derm }}=\sum_{i=1}^{n} \mathrm{HQ}_{\text {ing/derm }} \text {, }
$$

where $\mathrm{HI}_{\mathrm{ing} / \text { derm }}$ is the hazard index via ingestion or dermal contact (unitless). HI $>1$ indicated a potential for an adverse effect on human health [35].

\section{Results and Discussion}

3.1. Physical Characteristics. The physical condition of a water body strongly influences the chemical and biological processes that occur in the water column and consequently its ecological and chemical status. The mineral constituents existing in water determine the aptness of water. Water quality parameters ( $T, \mathrm{pH}$, TDS, and DO) in three seasons along with international/national water quality guidelines are given in Table 2. The data showed that average measured temperature values were $31.6,24.3$, and $13.8^{\circ} \mathrm{C}$ in premonsoon, monsoon, and postmonsoon, respectively. The $\mathrm{pH}$ values of the surface water ranged from 7.8 to 8.3 , from 7.2 to 7.8 , and from 6.4 to 6.8 in premonsoon, monsoon, and postmonsoon seasons, respectively. Consequently, the water samples were slightly alkaline in nature having carbonate species as $\mathrm{HCO}_{3}{ }^{1-}$ in premonsoon and monsoon [40], whereas they were slightly acidic in postmonsoon which could be due to human activities such as use of fertilizer and timber harvesting [41]. The lowest $\mathrm{pH}$ (6.4) was found in postmonsoon at site S5 near to Khaliqabad and Kakra towns, while the highest $\mathrm{pH}$ (8.3) was found in the samples near the industrial area of Mirpur city during premonsoon. The solubility of metals is generally lowered by elevating $\mathrm{pH}$ and increased by lowering $\mathrm{pH}$, discharging free metal ions into the overlying water [42].

Total dissolved solid (TDS) is an important parameter as it can affect the taste of water. Concentrations of TDS are generally related to human activities such as urban water runoffs, municipal wastewater discharges, and agricultural activities in the catchments areas. The contents of TDS ranged from 86.3 to $229 \mathrm{mg} / \mathrm{L}$, from 99.2 to $385 \mathrm{mg} / \mathrm{L}$, and from 74.2 to $139 \mathrm{mg} / \mathrm{L}$ with mean values of $92.0,139$, and $79.4 \mathrm{mg} / \mathrm{L}$ in premonsoon, monsoon, and postmonsoon seasons, respectively. Water having TDS less than $1000 \mathrm{mg} / \mathrm{L}$ is generally considered fresh/acceptable [43]. Consequently, surface waters from the Lake were considered fresh with respect to TDS levels in all seasons. In premonsoon and monsoon the highest and lowest values of TDS were found at sites S2 and S5, whereas in postmonsoon they were found at sites $\mathrm{S} 1$ and $\mathrm{S} 5$, respectively.

The dissolved oxygen (DO) in surface water ranged from 4.2 to $4.9 \mathrm{mg} / \mathrm{L}$ (mean: $4.3 \mathrm{mg} / \mathrm{L}$ ), from 6.0 to $6.5 \mathrm{mg} / \mathrm{L}$ (mean: $6.1 \mathrm{mg} / \mathrm{L}$ ), and from 6.4 to $7.4 \mathrm{mg} / \mathrm{L}$ (mean: $6.5 \mathrm{mg} / \mathrm{L}$ ) in premonsoon, monsoon, and postmonsoon seasons, respectively. DO concentration of greater than $5 \mathrm{mg} / \mathrm{L}$ is recommended to support the biota in aquatic ecosystem [28]. Flow regime, 
TABLE 2: Descriptive statistics for trace metals $(\mu \mathrm{g} / \mathrm{L})$ and water quality parameters in comparison with national/international guidelines.

\begin{tabular}{|c|c|c|c|c|c|c|c|c|c|c|c|c|c|}
\hline & $\mathrm{Cd}$ & $\mathrm{Co}$ & $\mathrm{Cr}$ & $\mathrm{Cu}$ & $\mathrm{Fe}$ & $\mathrm{Mn}$ & $\mathrm{Ni}$ & $\mathrm{Pb}$ & $\mathrm{Zn}$ & $T$ & $\mathrm{pH}$ & TDS & $\mathrm{DO}$ \\
\hline \multicolumn{14}{|l|}{ Premonsoon } \\
\hline Mean & 36.3 & 235 & 75.1 & 20.3 & 128 & 13.1 & 313 & 339 & 31.2 & 31.6 & 7.9 & 92.0 & 4.3 \\
\hline Median & 30.5 & 231 & 52.5 & 16.0 & 127 & 10.0 & 322 & 241 & 30.5 & 31.5 & 8.1 & 82.4 & 4.6 \\
\hline Max & 103 & 501 & 312 & 56.0 & 381 & 59.0 & 682 & 1501 & 76.0 & 32.5 & 8.3 & 229 & 4.9 \\
\hline \multicolumn{14}{|l|}{ Monsoon } \\
\hline Mean & 31.1 & 157 & 67.2 & 14.4 & 88.5 & 8.16 & 126 & 226 & 7.84 & 24.3 & 7.4 & 139 & 6.1 \\
\hline Median & 30.5 & 116 & 54.0 & 11.0 & 66.5 & 8.00 & 127 & 228 & 5.00 & 24.4 & 7.4 & 131 & 6.1 \\
\hline Max & 53.0 & 547 & 194 & 55.0 & 278 & 24.0 & 415 & 465 & 72.0 & 28.1 & 7.8 & 384 & 6.5 \\
\hline \multicolumn{14}{|l|}{ Postmonsoon } \\
\hline Mean & 18.3 & 103 & 21.0 & 13.7 & 109 & 18.9 & 124 & 129 & 11.7 & 13.8 & 6.4 & 79.4 & 6.5 \\
\hline Median & 17.0 & 99.0 & 17.0 & 12.5 & 78.5 & 18.0 & 116 & 124 & 10.5 & 13.8 & 6.4 & 77.0 & 6.5 \\
\hline Max & 40.0 & 254 & 63.0 & 30.0 & 454 & 43.0 & 405 & 267 & 31.0 & 14.2 & 6.8 & 139 & 7.4 \\
\hline \multicolumn{14}{|c|}{ Water quality criteria for drinking water } \\
\hline WHO (2008) & 3 & 40 & 50 & 2000 & 300 & 100 & 70 & 10 & 3000 & - & $6.5-8.5$ & 1200 & - \\
\hline USEPA (2009), MCL & 5 & & 100 & 1300 & 300 & 50 & 700 & 15 & 5000 & - & $6.5-8.5$ & 500 & - \\
\hline EC (1998) & 5 & & 50 & 2000 & 200 & & 20 & 10 & 100 & & - & - & - \\
\hline Pak-EPA (2008) & 10 & & 50 & 2000 & & 500 & 20 & 50 & 5000 & - & $6.5-8.5$ & 1000 & - \\
\hline \multicolumn{14}{|c|}{ Freshwater quality criteria for protection of aquatic life } \\
\hline USEPA (2006), CMC (acute) & 2 & & 16 & 13 & 1000 & & 470 & 65 & 120 & - & - & - & - \\
\hline USEPA (2006), CCC (chronic) & 2.5 & & 11 & 9 & 1000 & & 52 & 3 & & - & - & - & - \\
\hline
\end{tabular}

$T$ : temperature $\left({ }^{\circ} \mathrm{C}\right)$; TDS: total dissolved solids $(\mathrm{mg} / \mathrm{L})$; DO: dissolved oxygen $(\mathrm{mg} / \mathrm{L})$; CMC: criterion maximum concentration; CCC: criterion continuous concentration.

seasonal influences, and anthropic effects can be the causes of DO variations [44]. The release of unprocessed solid wastes from poultry farms and farmlands and municipal wastes from surrounding areas could be the possible reason for lower DO levels in premonsoon. Consequently, the aquatic ecosystem was under stress due to low DO levels. Although same types of inputs were also observed in monsoon and postmonsoon, their effects were insignificant due to dilution with plenty of water. Moreover, the lower DO levels could also be due to relatively higher temperature in premonsoon [41].

Measured values of $\mathrm{pH}$ in surface water were found to be within permissible limits of WHO [45], USEPA [46], and Pak-EPA [47] in premonsoon and monsoon seasons, whereas in postmonsoon they were found to be below permissible limits in $55 \%$ of the samples. However, average values of TDS in the water samples were found to be within WHO, USEPA, and Pak-EPA guidelines (Table 2). It indicated that the water from Mangla Lake was fresh having low salinity and minerals [48].

3.2. Spatial Variations of Trace Metals. During the study period, all trace metals did not show significant spatial variations $(p<0.05)$ in the water reservoir. Highest levels of the metals were observed at sites $\mathrm{S} 3$ and $\mathrm{S} 4$ in all seasons. The total concentrations of trace metals in premonsoon season showed an average level of $132 \mu \mathrm{g} / \mathrm{L}$, with following order: S4 $(181 \mu \mathrm{g} / \mathrm{L})>\mathrm{S} 3(147 \mu \mathrm{g} / \mathrm{L})>\mathrm{S} 5(125 \mu \mathrm{g} / \mathrm{L})>\mathrm{S} 1(106 \mu \mathrm{g} / \mathrm{L})>\mathrm{S} 2$ $(103 \mu \mathrm{g} / \mathrm{L}) ;$ meanwhile, in monsoon season, the average level was $81.0 \mu \mathrm{g} / \mathrm{L}$, and the relative order was $\mathrm{S} 4(105 \mu \mathrm{g} / \mathrm{L})>\mathrm{S} 3$ $(89.0 \mu \mathrm{g} / \mathrm{L})>\mathrm{S} 5(80.0 \mu \mathrm{g} / \mathrm{L})>\mathrm{S} 1(68.0 \mu \mathrm{g} / \mathrm{L})>\mathrm{S} 2(61.0 \mu \mathrm{g} / \mathrm{L})$.

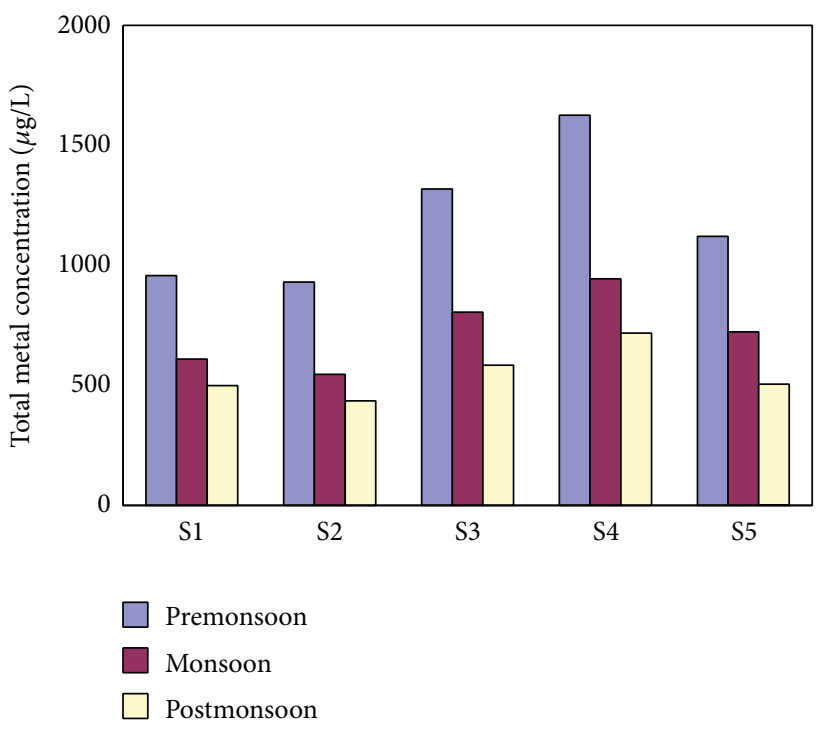

FIGURE 2: Total concentrations of trace metals at different sampling sites.

Likewise, the total concentrations of trace metals in postmonsoon exhibited an average value of $61.0 \mu \mathrm{g} / \mathrm{L}$, followed in order of abundance by site $\mathrm{S} 4(80.0 \mu \mathrm{g} / \mathrm{L})>\mathrm{S} 3(65.0 \mu \mathrm{g} / \mathrm{L})>$ S5 $(56.0 \mu \mathrm{g} / \mathrm{L}) \approx \mathrm{S} 1(56.0 \mu \mathrm{g} / \mathrm{L})>\mathrm{S} 2(48.0 \mu \mathrm{g} / \mathrm{L})$. Overall order of total metal concentrations remained the same in all seasons: $\mathrm{S} 4>\mathrm{S} 3>\mathrm{S} 5>\mathrm{S} 1>\mathrm{S} 2$ (Figure 2). 
Spatial distribution of total concentrations of the metals showed a decreasing trend from the sites near highly urban areas to the sites near suburban areas. The higher total concentrations were measured at sites S4 and S3 which are located at highly urbanized area (Mirpur city), while the lower total concentrations were found at sampling sites S1 and S2 which are close to the less populated areas of the Lake in all seasons. Moreover, the water samples collected near the Lake outlet had the lowest concentrations. It could be due to dilution and transfer of metals from water column towards the sediments $[4,7,49]$. Among the metals, Fe, Co, $\mathrm{Pb}$, and $\mathrm{Ni}$ were the most abundant elements in the reservoir, whereas $\mathrm{Cu}, \mathrm{Mn}$, and $\mathrm{Zn}$ were less abundant. Nickel and lead showed maximum concentrations at sites S3 and S4, while Fe indicated higher concentrations at sites S4 and S5 in all seasons. However, the maximum levels of $\mathrm{Cd}$ and $\mathrm{Co}$ were found at sites S3 and S4 in pre- and postmonsoon seasons and at sites $\mathrm{S} 4$ and $\mathrm{S} 5$ in monsoon. The mean order of metals level was $\mathrm{Pb}(339 \mu \mathrm{g} / \mathrm{L})>\mathrm{Ni}(331 \mu \mathrm{g} / \mathrm{L})>\mathrm{Co}$ $(235 \mu \mathrm{g} / \mathrm{L})>\mathrm{Fe}(128 \mu \mathrm{g} / \mathrm{L})>\mathrm{Cr}(75.1 \mu \mathrm{g} / \mathrm{L})>\mathrm{Cd}(36.3 \mu \mathrm{g} / \mathrm{L})>$ $\mathrm{Zn}(31.2 \mu \mathrm{g} / \mathrm{L})>\mathrm{Cu}(20.3 \mu \mathrm{g} / \mathrm{L})>\mathrm{Mn}(13.1 \mu \mathrm{g} / \mathrm{L})$ in premonsoon, $\mathrm{Pb}(226 \mu \mathrm{g} / \mathrm{L})>\mathrm{Co}(157 \mu \mathrm{g} / \mathrm{L})>\mathrm{Ni}(126 \mu \mathrm{g} / \mathrm{L})>$ $\mathrm{Fe}(88.5 \mu \mathrm{g} / \mathrm{L})>\mathrm{Cr}(67.2 \mu \mathrm{g} / \mathrm{L})>\mathrm{Cd}(31.1 \mu \mathrm{g} / \mathrm{L})>\mathrm{Cu}$ $(14.4 \mu \mathrm{g} / \mathrm{L})>\mathrm{Zn}(7.84 \mu \mathrm{g} / \mathrm{L})>\mathrm{Mn}(8.16 \mu \mathrm{g} / \mathrm{L})$ in monsoon, and $\mathrm{Pb}(129 \mu \mathrm{g} / \mathrm{L})>\mathrm{Ni}(124 \mu \mathrm{g} / \mathrm{L})>\mathrm{Fe}(109 \mu \mathrm{g} / \mathrm{L})>$ Co $(103 \mu \mathrm{g} / \mathrm{L})>\operatorname{Cr}(21.0 \mu \mathrm{g} / \mathrm{L})>\mathrm{Mn}(18.9 \mu \mathrm{g} / \mathrm{L})>\mathrm{Cd}$ $(18.3 \mu \mathrm{g} / \mathrm{L})>\mathrm{Cu}(13.7 \mu \mathrm{g} / \mathrm{L})>\mathrm{Zn}(11.7 \mu \mathrm{g} / \mathrm{L})$ in postmonsoon. For all the seasons, high concentrations of $\mathrm{Co}, \mathrm{Ni}$, and $\mathrm{Pb}$ were observed at sites S3 and S4 which are under the influence of urbanization and industrialization.

3.3. Seasonal Variations of Trace Metals. The average concentrations of trace metals in all seasons are shown in Table 2. Sum of concentrations of all the metals (Cd, Co, $\mathrm{Cr}, \mathrm{Cu}, \mathrm{Fe}, \mathrm{Mn}, \mathrm{Ni}, \mathrm{Pb}$, and $\mathrm{Zn}$ ) in Lake water showed the average values of $1191 \mu \mathrm{g} / \mathrm{L}, 726 \mu \mathrm{g} / \mathrm{L}$, and $549 \mu \mathrm{g} / \mathrm{L}$ in premonsoon, monsoon, and postmonsoon seasons, respectively. The results indicated that the metal concentrations were higher in premonsoon as compared to the other seasons irrespective of the sampling sites. It may be owing to the varying seasonal inputs to the Lake water due to hydrological regime and seasonal anthropogenic activities. This may be attributed to the high evaporation and intense anthropogenic activities (agriculture and high degree of domestic/industrial activities) in summer (premonsoon) to elevate the total concentrations of metals $[50,51]$. High precipitation and large water inputs from the tributaries and rivers were the most plausible explanations for the lowest total concentrations in monsoon and postmonsoon seasons. High precipitation in monsoon mixes large volumes of uncontaminated runoff water with contaminated water which resulted in decline of total metal concentrations in Lake water [4].

Most of the trace metals showed significant tempo$\mathrm{ral} /$ seasonal variations $(p<0.05)$. Among the metals, $\mathrm{Cd}, \mathrm{Co}, \mathrm{Cr}, \mathrm{Cu}, \mathrm{Ni}$, and $\mathrm{Pb}$ displayed the following order: premonsoon > monsoon > postmonsoon; meanwhile, for $\mathrm{Zn}$ and $\mathrm{Fe}$, the order was premonsoon $>$ postmonsoon $>$ monsoon. However, Mn showed different order: postmonsoon $>$ premonsoon $>$ monsoon. About $80 \%$ of annual precipitation is associated with monsoon season resulting in dilution of the pollutants. Some of the metals $(\mathrm{Fe}, \mathrm{Mn}$, and $\mathrm{Zn}$ ) showed higher contributions in varying hydrological seasonality, which may be attributed to mixed sources due to natural contributions and anthropogenic activities [12, 51]. Thus, precipitation and seasonal anthropogenic activities played important roles in distribution of metal levels in surface water of the Lake [12].

3.4. Comparison with National and International Studies. Average metal concentrations in water samples from Mangla Lake were also compared with the reported studies from different reservoirs in national and international studies (Table 3). Some of the metals (Cd, $\mathrm{Co}, \mathrm{Cr}, \mathrm{Ni}$, and $\mathrm{Pb}$ ) showed higher contents in the Mangla Lake compared with other studies in all seasons except Co in postmonsoon levels which were lower than those reported for the Legnica Lake (Southwest Poland), Dil Deresi Stream (Turkey), Anthropogenic Lake (West Poland), and Lake Gilow (Poland) $[4,7,8,52-$ 56]. $\mathrm{Cu}$ and $\mathrm{Zn}$ exhibited lower concentrations than those reported for the Dil Deresi Stream (Turkey), Kanyaboli Lake (Kenya), Anthropogenic Lake (West Poland), Legnica Lake (Southwest Poland), and Lake Gilow (Poland) in all seasons, while $\mathrm{Fe}$ showed lower concentrations than those reported for the Dil Deresi stream (Turkey) and Anthropogenic Lake (West Poland) in all seasons. Manganese showed lower average levels than those reported for Kanyaboli Lake (Kenya), Anthropogenic Lake (West Poland), Legnica Lake (Southwest Poland), and Lake Gilow (Poland) in all seasons.

Average metal levels measured in the present study were compared with previously reported levels [57] from Mangla reservoir which showed almost comparable levels for $\mathrm{Cd}, \mathrm{Cu}$, $\mathrm{Mn}, \mathrm{Ni}, \mathrm{Pb}$, and $\mathrm{Zn}$ with few exceptions; nevertheless, in the present study, average levels of $\mathrm{Cr}$ were significantly higher than the reported levels. In comparison with other national reported studies related to surface water (Table 3 ), the mean concentrations of $\mathrm{Cd}$ were relatively higher in premonsoon and monsoon than levels reported in other studies [58-61]. The average levels of $\mathrm{Cr}$ and $\mathrm{Ni}$ were found to be elevated in all seasons compared to others; Co levels (premonsoon and monsoon) were noted to be higher than levels in Rawal lake (summer) and Manchar lake; and $\mathrm{Pb}$ average levels were elevated compared to others except Mangla Lake in premonsoon and postmonsoon. However, Fe, Mn, and $\mathrm{Zn}$ contents were noted to be lower than others. Moreover, $\mathrm{Cu}$ levels were comparable to other reported levels.

3.5. Comparison with Guideline/Standard Values. Metal concentrations in different seasons were compared with water quality guidelines for drinking water $[45-47,62]$ and the protection of freshwater aquatic life [63] (Table 2). The maximum concentrations of $\mathrm{Cu}$ and $\mathrm{Zn}$ and the average values of $\mathrm{Fe}$ and $\mathrm{Mn}$ in the reservoir were lower than the maximum permitted concentrations established by EC, USEPA, WHO, and Pak-EPA guidelines. The maximum concentrations of $\mathrm{Mn}$ in premonsoon were higher than USEPA, while the maximum value of $\mathrm{Fe}$ in premonsoon and postmonsoon exceeded WHO, USEPA, EC, and Pak-EPA guidelines. The maximum and average values of $\mathrm{Cd}$ and $\mathrm{Pb}$ in the Lake 
TABLE 3: Comparison of mean trace metals concentrations $(\mu \mathrm{g} / \mathrm{L})$ in surface water of Mangla Lake with national and international studies.

\begin{tabular}{|c|c|c|c|c|c|c|c|c|c|c|}
\hline & $\mathrm{Cd}$ & Co & $\mathrm{Cr}$ & $\mathrm{Cu}$ & $\mathrm{Fe}$ & $\mathrm{Mn}$ & $\mathrm{Ni}$ & $\mathrm{Pb}$ & $\mathrm{Zn}$ & Reference \\
\hline \multicolumn{11}{|l|}{ Mangla Lake } \\
\hline Premonsoon & 36.3 & 75.1 & 235 & 20.3 & 128 & 13.1 & 313 & 339 & 31.2 & This study \\
\hline \multicolumn{11}{|l|}{ Mangla Lake } \\
\hline Monsoon & 31.1 & 67.2 & 157 & 14.4 & 88.5 & 8.16 & 126 & 226 & 7.84 & This study \\
\hline \multicolumn{11}{|l|}{ Mangla Lake } \\
\hline Postmonsoon & 18.3 & 21.0 & 103 & 13.7 & 109 & 18.9 & 124 & 129 & 11.7 & This study \\
\hline Kralkızı Dam Reservoir, Turkey & 0.036 & - & 22.06 & 2.83 & 58.63 & - & 15.75 & 2.56 & 5.02 & {$[4]$} \\
\hline Dicle Dam Reservoir, Turkey & 0.030 & - & 18.58 & 2.12 & 62.07 & - & 15.86 & 1.84 & 4.12 & {$[4]$} \\
\hline Batman Dam Reservoir, Turkey & 0.044 & - & 16.5 & ND & 57.66 & - & 15.96 & 1.56 & 4.09 & {$[4]$} \\
\hline Danjiangkou Reservoir, China & 1.17 & 1.08 & 6.29 & 13.32 & 19.14 & 5.69 & 1.73 & 10.59 & 2.02 & {$[7]$} \\
\hline Dil Deresi stream, Turkey & 8 & 21 & 42 & 37 & 4030 & - & - & 120 & 700 & {$[8]$} \\
\hline Taihu Lake, China & 0.06 & - & 0.99 & 5.81 & - & - & 5.34 & 2.74 & 15.86 & {$[52]$} \\
\hline Kanyaboli Lake, Kenya & 4.4 & 6.06 & 21.54 & 23.95 & - & 284.27 & 16.38 & 20.65 & 32.79 & {$[53]$} \\
\hline Kainji Dam, Nigeria & - & 1.2 & 2.2 & 1.3 & 13 & 9 & 0.90 & 1.2 & 0.90 & {$[54]$} \\
\hline Anthropogenic Lake in West Poland & 2.9 & 24 & 3.3 & 48 & 154 & 1230 & 4 & 111 & 207 & {$[55]$} \\
\hline Legnica Lake in Southwest Poland & 1.72 & 65 & 1.1 & 29 & 6 & 670 & 68.2 & 0.21 & 204 & {$[56]$} \\
\hline Lake Gilow, Poland & 0.58 & 27 & 0.9 & 48 & 6 & 390 & 76 & 0.5 & 167 & {$[56]$} \\
\hline \multicolumn{11}{|l|}{ Mangla Lake, Pakistan } \\
\hline Summer & 30 & 250 & 80 & 20 & 150 & 10 & 130 & 380 & 30 & {$[57]$} \\
\hline \multicolumn{11}{|l|}{ Mangla Lake, Pakistan } \\
\hline Winter & 30 & 160 & 70 & 20 & 130 & 20 & 110 & 340 & 30 & {$[57]$} \\
\hline \multicolumn{11}{|l|}{ Rawal Lake, Pakistan } \\
\hline Summer & 6 & 11 & 9 & 10 & 93 & 4 & - & 162 & 14 & {$[58]$} \\
\hline \multicolumn{11}{|l|}{ Rawal Lake, Pakistan } \\
\hline Winter & 25 & 204 & 97 & 17 & 76 & 13 & - & 223 & 22 & {$[58]$} \\
\hline Khanpur Lake, Pakistan & 20 & 114 & 46 & 9 & 51 & 11 & - & 221 & 15 & [59] \\
\hline \multicolumn{11}{|l|}{ Manchar Lake, Pakistan } \\
\hline Summer & 6.14 & 41.0 & 8.23 & 20.4 & 3228 & 75.8 & 35.8 & 87.6 & 774 & {$[60]$} \\
\hline \multicolumn{11}{|l|}{ Manchar Lake, Pakistan } \\
\hline Winter & 4.22 & 34.7 & 6.84 & 18.2 & 2780 & 64.7 & 31.0 & 78.7 & 683 & {$[60]$} \\
\hline Manchar Lake, Pakistan & 5.3 & 38.9 & 7.64 & 18.9 & 2960 & 72.6 & 35.0 & 82.4 & 730 & [61] \\
\hline
\end{tabular}

ND: not detected.

were higher than the water quality guidelines set by WHO, USEPA, EC, and Pak-EPA in three seasons. The maximum and average concentrations of $\mathrm{Co}$ in three seasons were higher than WHO guidelines, while maximum value of $\mathrm{Cr}$ in all seasons and its average value in premonsoon and monsoon were higher than WHO, EC, and Pak-EPA guidelines, whereas maximum concentration of $\mathrm{Cr}$ exceeded USEPA permissible limits in premonsoon and monsoon seasons. The maximum and average concentrations of $\mathrm{Ni}$ in three seasons were higher than WHO, EC, and PakEPA guidelines, while they were below USEPA guidelines. When the measured metal concentrations were compared with USEPA guidelines, for aquatic life protection [63], it was found that the maximum concentrations of $\mathrm{Cd}, \mathrm{Cr}, \mathrm{Cu}$, and $\mathrm{Pb}$ exceeded the criterion maximum concentrations (CMC) and criterion continuous concentration (CCC) values, while $\mathrm{Ni}$ was higher than the criterion continuous concentration (CCC) values in all seasons.
In this study, $100 \%$ of the water samples in monsoon and $>90 \%$ samples in premonsoon and postmonsoon for $\mathrm{Cd}$ and $\mathrm{Pb}$ exceeded EC, WHO, USEPA, and Pak-EPA guidelines. About $58 \%$ of the samples for $\mathrm{Cr}$ in premonsoon and monsoon and $>92 \%$ for $\mathrm{Ni}$ in all seasons were found to exceed WHO, EC, and Pak-EPA guidelines. Cobalt concentrations were higher than WHO guidelines in $96 \%, 86 \%$, and $84 \%$ of samples in premonsoon, monsoon, and postmonsoon, respectively. However, the measured concentrations of $\mathrm{Fe}$ in more than $90 \%$ of samples were lower, whereas $\mathrm{Cu}, \mathrm{Mn}$, and $\mathrm{Zn}$ levels were found to be lower in $100 \%$ of the water samples than the national and international guidelines in all seasons. Thus $\mathrm{Cd}, \mathrm{Co}, \mathrm{Ni}$, and $\mathrm{Pb}$ were potential pollutants in the reservoir and they might pose health risks for the local population. For example, Cd causes renal tubular dysfunction, bone fragility, kidney dysfunction, skeletal damage, and reproductive disorders; Co causes polycythemia, heart dysfunctions, thyroid alterations, testicular deterioration and 
TABLE 4: Principal component loadings* for trace metals in surface water of Mangla Lake.

\begin{tabular}{lcccc}
\hline & PC1 & PC2 & PC3 & PC4 \\
\hline Eigenvalue & 1.85 & 1.47 & 1.23 & 1.22 \\
Total variance (\%) & 38.6 & 20.4 & 15.7 & 10.6 \\
Cumulative variance (\%) & 38.6 & 59.0 & 74.7 & 85.3 \\
\hline $\mathrm{Cd}$ & $\mathbf{0 . 8 3}$ & - & - & - \\
$\mathrm{Co}$ & $\mathbf{0 . 8 3}$ & - & - & - \\
$\mathrm{Cr}$ & - & $\mathbf{0 . 8 3}$ & - & - \\
$\mathrm{Cu}$ & - & 0.35 & $\mathbf{0 . 6 7}$ & 0.25 \\
$\mathrm{Fe}$ & 0.29 & - & - & $\mathbf{0 . 6 7}$ \\
$\mathrm{Mn}$ & - & - & - & $\mathbf{0 . 6 1}$ \\
$\mathrm{Ni}$ & 0.26 & $\mathbf{0 . 6 7}$ & - & - \\
$\mathrm{Pb}$ & - & $\mathbf{0 . 7 3}$ & - & - \\
$\mathrm{Zn}$ & - & 0.33 & $\mathbf{0 . 6 9}$ & - \\
\hline
\end{tabular}

${ }^{*}$ PC loadings $<0.25$ are omitted.

wither, lesser development, and persistence of progenies; Ni may cause skin allergies, lung fibrosis, dermatitis, and cancer of the respiratory tract; and $\mathrm{Pb}$ may affect central nervous system especially in young children, kidney, and cardiovascular system [64-66].

3.6. Multivariate Statistical Analyses. Principal component analysis (PCA) was used to find out the plausible contributing sources of selected metals in water reservoir. This method allows identifying different groups of metals that correlate and thus can be considered as having a similar behavior and common origin [67]. The numbers of significant PCs were selected on the basis of Kaiser criterion with eigenvalue greater than 1 [68]. Four PCs with eigenvalues $>1$ which explained about $85.3 \%$ of the total variance were obtained. The corresponding PCs, variable loadings, and the explained variance are shown in Table 4. First component (PC 1), which accounted for $38.6 \%$ of the total variance, showed strong positive loadings $(>0.70)$ for $\mathrm{Cd}$ and $\mathrm{Co}$. The second component (PC 2) contributed to $\mathrm{Cr}, \mathrm{Ni}$, and $\mathrm{Pb}$ elucidating $20.4 \%$ of total variance. These two components could be attributed to anthropogenic activities in the area, such as agricultural activities, discharge of untreated poultry, municipal/industrial wastes, and atmospheric deposition [69-72]. The studied area is under tremendous pressure of urbanization, industrialization, land cultivation, reservoir upgradation, and vehicular load. The third component (PC 3) which accounted for $15.7 \%$ of the total variance was associated with $\mathrm{Cu}$ and $\mathrm{Zn}$, whereas PC 4 (10.6\% of total variance) showed elevated loadings for $\mathrm{Fe}$ and $\mathrm{Mn}$. The association of $\mathrm{Cu}, \mathrm{Fe}, \mathrm{Mn}$, and $\mathrm{Zn}$ in the Lake reflected their natural background levels. Table 2 revealed that mean concentrations of these metals never exceeded the maximum permitted concentrations established by EC, WHO, Pak-EPA, and USEPA water quality guidelines. Therefore, the metals were predominantly derived from natural sources such as weathering of parent material and subsequent pedogenesis.

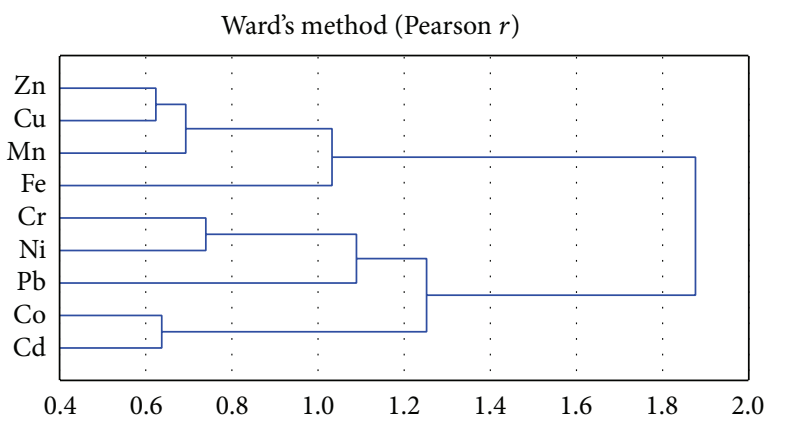

FIGURE 3: Dendrogram showing clustering of trace metals in Mangla Lake.

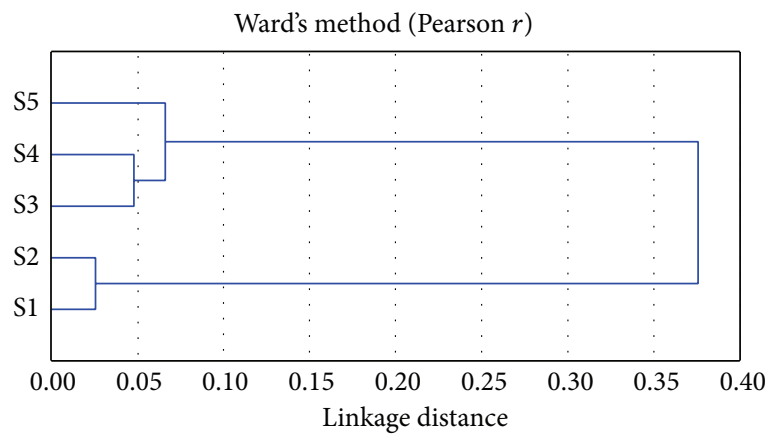

FIGURE 4: Dendrogram showing clustering of sampling sites in Mangla Lake.

Cluster analysis (CA) of the metal data was performed to explore the grouping of trace metals in surface water of Mangla Lake, Pakistan. It is shown as a dendrogram in Figure 3 , where the metals were grouped into two main clusters. Cluster 1 consisted of $\mathrm{Cu}-\mathrm{Zn}-\mathrm{Mn}-\mathrm{Fe}$, while cluster 2 was composed of $\mathrm{Cd}-\mathrm{Co}-\mathrm{Pb}-\mathrm{Ni}-\mathrm{Cr}$. The metals in each cluster had similar characteristic features and possibly similar inputs. Consequently, the metals grouped in cluster 1 were considered to be contributed by natural inputs, whereas the metals in cluster 2 were likely to be included by anthropic intrusions in surface water of Mangla Lake, Pakistan. In this study, exactly similar elemental grouping was shown by PCA and $\mathrm{CA}$; $\mathrm{Cd}$ shared cluster and $\mathrm{PC}$ with $\mathrm{Co}, \mathrm{Cu}$ with $\mathrm{Zn}, \mathrm{Mn}$ with $\mathrm{Fe}$, and $\mathrm{Cr}$ with $\mathrm{Ni}-\mathrm{Pb}$.

Cluster analysis (CA) was also applied to the dataset to group the similar sampling sites (spatial variability). Spatial CA rendered a dendrogram (Figure 4), where all five sampling sites were grouped into three statistically significant clusters. Cluster 1 consisted of site S5; cluster 2 consisted of two sites, S3 and S4; and cluster 3 consisted of two sites, S1 and S2. The sites in each cluster had similar characteristic features and possibly similar sources. The results manifested that sites S3 and S4 had the highest concentrations of $\mathrm{Cd}, \mathrm{Co}, \mathrm{Cr}$, $\mathrm{Ni}$, and $\mathrm{Pb}$; site $\mathrm{S} 5$ exhibited moderate metal concentrations, while sites S1 and S2 had the lowest concentrations of the studied metals. Consequently, sites S3 and S4 were relatively heavily polluted by the metals; site S5 was moderately polluted, whereas sites S1 and S2 indicated low metal pollution in the Lake. 
TABLE 5: Hazard quotient (HQ) and hazard index (HI) for each metal in surface water of Mangla Lake.

\begin{tabular}{|c|c|c|c|c|c|c|c|c|}
\hline \multirow{2}{*}{ Metal } & \multirow{2}{*}{$\begin{array}{c}\mathrm{RfD}_{\text {ing }} \\
(\mu \mathrm{g} / \mathrm{kg} \text {-day })\end{array}$} & \multirow{2}{*}{$\begin{array}{c}\mathrm{RfD}_{\text {derm }} \\
(\mu \mathrm{g} / \mathrm{kg} \text {-day })\end{array}$} & \multicolumn{2}{|c|}{$\mathrm{HQ}_{\text {ing }}$} & \multicolumn{2}{|c|}{$\mathrm{HQ}_{\text {derm }}$} & \multicolumn{2}{|c|}{$\mathrm{HI}=\sum \mathrm{HQs}$} \\
\hline & & & Child & Adult & Child & Adult & Child & Adult \\
\hline \multicolumn{9}{|c|}{ Premonsoon } \\
\hline $\mathrm{Cd}$ & 0.5 & 0.025 & $8.3 E+00$ & $2.2 E+00$ & $6.1 E-01$ & $2.1 E-01$ & $9.0 E+00$ & $2.4 E+00$ \\
\hline Co & 0.3 & 0.06 & $9.0 E+01$ & $2.4 E+01$ & $6.6 E-01$ & $2.2 E-01$ & $9.1 E+01$ & $2.4 E+01$ \\
\hline $\mathrm{Cr}$ & 3 & 0.075 & $2.9 E+00$ & $7.5 E-01$ & $8.4 E-01$ & $2.9 E-01$ & $3.7 E+00$ & $1.0 E+00$ \\
\hline $\mathrm{Cu}$ & 40 & 8 & $5.8 E-02$ & $1.5 E-02$ & $1.1 E-03$ & $3.6 E-04$ & $5.9 E-02$ & $1.6 E-02$ \\
\hline $\mathrm{Fe}$ & 700 & 140 & $2.1 E-02$ & $5.5 E-03$ & $3.9 E-04$ & $1.3 E-04$ & $2.1 E-02$ & $5.6 E-03$ \\
\hline $\mathrm{Mn}$ & 24 & 0.96 & $5.6 E-02$ & $1.6 E-02$ & $5.8 E-03$ & $2.0 E-03$ & $6.1 E-02$ & $1.8 E-02$ \\
\hline $\mathrm{Ni}$ & 20 & 5.4 & $1.5 E+00$ & $4.7 E-01$ & $9.8 E-03$ & $3.3 E-03$ & $1.5 E+00$ & $4.8 E-01$ \\
\hline $\mathrm{Pb}$ & 1.4 & 0.42 & $2.2 E+01$ & $7.3 E+00$ & $1.4 E-01$ & $4.6 E-02$ & $2.2 E+01$ & $7.3 E+00$ \\
\hline $\mathrm{Zn}$ & 300 & 60 & $1.2 E-02$ & $3.1 E-03$ & $1.3 E-04$ & $4.5 E-05$ & $1.2 E-02$ & $3.2 E-03$ \\
\hline \multicolumn{9}{|c|}{ Monsoon } \\
\hline $\mathrm{Cd}$ & 0.5 & 0.025 & $7.2 E+00$ & $1.9 E+00$ & $5.3 E-01$ & $1.8 E-01$ & $7.7 E+00$ & $2.1 E+00$ \\
\hline Co & 0.3 & 0.06 & $6.0 E+01$ & $1.6 E+01$ & $4.4 E-01$ & $1.5 E-01$ & $6.1 E+01$ & $1.6 E+01$ \\
\hline $\mathrm{Cr}$ & 3 & 0.075 & $2.6 E+00$ & $6.7 E-01$ & $7.6 E-01$ & $2.6 E-01$ & $3.3 E+00$ & $9.3 E-01$ \\
\hline $\mathrm{Cu}$ & 40 & 8 & $4.1 E-02$ & $1.1 E-02$ & $7.6 E-04$ & $2.6 E-04$ & $4.2 E-02$ & $1.1 E-02$ \\
\hline $\mathrm{Fe}$ & 700 & 140 & $1.5 E-02$ & $3.8 E-03$ & $2.7 E-04$ & $9.0 E-05$ & $1.5 E-02$ & $3.9 E-03$ \\
\hline $\mathrm{Mn}$ & 24 & 0.96 & $3.5 E-02$ & $1.0 E-02$ & $3.6 E-03$ & $1.2 E-03$ & $3.8 E-02$ & $1.1 E-02$ \\
\hline $\mathrm{Ni}$ & 20 & 5.4 & $6.0 E-01$ & $1.9 E-01$ & $3.9 E-03$ & $1.3 E-03$ & $6.1 E-01$ & $1.9 E-01$ \\
\hline $\mathrm{Pb}$ & 1.4 & 0.42 & $1.5 E+01$ & $4.9 E+00$ & $9.1 E-02$ & $3.1 E-02$ & $1.5 E+01$ & $4.9 E+00$ \\
\hline $\mathrm{Zn}$ & 300 & 60 & $3.0 E-03$ & $7.9 E-04$ & $3.3 E-05$ & $1.1 E-05$ & $3.0 E-03$ & $8.0 E-04$ \\
\hline \multicolumn{9}{|c|}{ Postmonsoon } \\
\hline $\mathrm{Cd}$ & 0.5 & 0.025 & $4.2 E+00$ & $1.1 E+00$ & $3.1 E-01$ & $1.0 E-01$ & $4.5 E+00$ & $1.2 E+00$ \\
\hline Co & 0.3 & 0.06 & $3.9 E+01$ & $1.0 E+01$ & $2.9 E-01$ & $9.8 E-02$ & $4.0 E+01$ & $1.0 E+01$ \\
\hline $\mathrm{Cr}$ & 3 & 0.075 & $8.1 E-01$ & $2.1 E-01$ & $2.4 E-01$ & $8.0 E-02$ & $1.0 E+00$ & $2.9 E-01$ \\
\hline $\mathrm{Cu}$ & 40 & 8 & $3.9 E-02$ & $1.0 E-02$ & $7.2 E-04$ & $2.4 E-04$ & $4.0 E-02$ & $1.1 E-02$ \\
\hline $\mathrm{Fe}$ & 700 & 140 & $1.8 E-02$ & $4.7 E-03$ & $3.3 E-04$ & $1.1 E-04$ & $1.8 E-02$ & $4.8 E-03$ \\
\hline $\mathrm{Mn}$ & 24 & 0.96 & $8.0 E-02$ & $2.4 E-02$ & $8.3 E-03$ & $2.8 E-03$ & $8.8 E-02$ & $2.7 E-02$ \\
\hline $\mathrm{Ni}$ & 20 & 5.4 & $6.0 E-01$ & $1.9 E-01$ & $3.9 E-03$ & $1.3 E-03$ & $6.0 E-01$ & $1.9 E-01$ \\
\hline $\mathrm{Pb}$ & 1.4 & 0.42 & $8.4 E+00$ & $2.8 E+00$ & $5.2 E-02$ & $1.8 E-02$ & $8.4 E+00$ & $2.8 E+00$ \\
\hline $\mathrm{Zn}$ & 300 & 60 & $4.5 E-03$ & $1.2 E-03$ & $4.9 E-05$ & $1.7 E-05$ & $4.5 E-03$ & $1.2 E-03$ \\
\hline
\end{tabular}

3.7. Human Health Risk Assessment. Table 5 shows the hazard quotient (HQ), hazard index (HI), and risk values for the oral and dermal exposures in premonsoon, monsoon, and postmonsoon seasons relating to children and adults. In premonsoon season, $\mathrm{HQ}_{\text {ing }}$ (hazard quotient by ingestion) of $\mathrm{Cd}$, $\mathrm{Co}, \mathrm{Cr}, \mathrm{Ni}$, and $\mathrm{Pb}$ for children was more than 1 implying that it may cause adverse health effects and potential noncarcinogenic concern. In case of adults, $\mathrm{HQ}_{\text {ing }}$ of $\mathrm{Cd}$ (2.2), Co (24), and $\mathrm{Pb}$ (7.3) was much higher than unity and $\mathrm{Cr}(0.75)$ was nearing unity indicating its serious health concerns. However, $\mathrm{HQ}_{\text {ing }}$ of the remaining metals for children and adults was less than 1 , suggesting that these metals posed little/no hazard through direct intake of the Lake water. The $\mathrm{HQ}_{\text {derm }}$ (hazard quotient by dermal absorption) of all the metals for adults and children was below unity, indicating that these metals posed little/no hazards via dermal absorption. The largest values of $H Q_{\text {derm }}$ were $0.84,0.66$, and 0.61 which were for $\mathrm{Cr}, \mathrm{Co}$, and $\mathrm{Cd}$ for children, respectively, demonstrating that these metals could cause potential adverse health effects via dermal absorption. Overall, $\mathrm{HI}$ of $\mathrm{Cd}, \mathrm{Co}, \mathrm{Cr}$, and $\mathrm{Pb}$ for adults and children exceeded 1 , and $\mathrm{HI}$ of $\mathrm{Ni}$ for children was near 1 . It can be concluded that the highest contributors to chronic risks were $\mathrm{Cd}, \mathrm{Co}, \mathrm{Cr}, \mathrm{Ni}$, and $\mathrm{Pb}$, while the lowest were $\mathrm{Fe}, \mathrm{Mn}$, and $\mathrm{Zn}$ for both the adults and children.

In monsoon season, $\mathrm{HQ}_{\text {ing }}$ for $\mathrm{Cd}, \mathrm{Co}, \mathrm{Cr}$, and $\mathrm{Pb}$ for children was higher than unity, while in case of adults, $\mathrm{HQ}_{\mathrm{ing}}$ for $\mathrm{Cd}, \mathrm{Co}$, and $\mathrm{Pb}$ was higher than 1 . However, $\mathrm{HQ}_{\text {derm }}$ was lower than unity for children and adults demonstrating that these metals posed no significant adverse health effects via dermal absorption. Generally, $\mathrm{HI}$ of $\mathrm{Cd}, \mathrm{Co}$, and $\mathrm{Pb}$ for children and adults exceeded 1 and HI of $\mathrm{Cr}$ was higher than unity for children and was near unity (0.93) for adults. Cd, $\mathrm{Co}, \mathrm{Cr}$, and $\mathrm{Pb}$ emerged as major pollutants in this season. In postmonsoon season, $\mathrm{HQ}_{\text {ing }}$ for children of $\mathrm{Cd}, \mathrm{Co}$, and $\mathrm{Pb}$ was higher than one and $\mathrm{Cr}$ and $\mathrm{Ni}$ were nearing one indicating potential noncarcinogenic adverse health risks via oral intake. For adults, $\mathrm{HQ}_{\text {ing }}$ for $\mathrm{Cd}, \mathrm{Co}$, and $\mathrm{Pb}$ was higher than unity. 
As a whole, it was revealed that $\mathrm{Cd}, \mathrm{Co}, \mathrm{Cr}, \mathrm{Ni}$, and $\mathrm{Pb}$ could pose severe health effects to the inhabitants through ingestion pathway in the studied seasons, whereas the remaining metals through oral pathway and all the studied metals via dermal pathway could cause little/no health concerns. Consequently, distinctive consideration should be paid to manage these toxic elements and to support healthy aquatic ecosystem. Nonetheless, uncertainties related to methodological features, such as water and dermal contact factor $\left(K_{p}\right)$, different exposure conditions, and temporal and spatial disparities in pollutants levels were not quantified. Furthermore, employed parameters were taken from USEPA, WHO, and elsewhere; they could not be definite to local situations. Therefore, a more detailed risk characterization related to the risk levels by the metals in the Mangla Lake is suggested.

\section{Conclusions}

Concentrations of trace metals $(\mathrm{Cd}, \mathrm{Co}, \mathrm{Cr}, \mathrm{Cu}, \mathrm{Fe}, \mathrm{Mn}$, $\mathrm{Ni}, \mathrm{Pb}$, and $\mathrm{Zn}$ ) in the water of the Mangla Lake, Pakistan, demonstrated significant seasonal variations. Irrespective of the sampling sites, the metal concentrations were lower in postmonsoon season compared to other seasons due to marked dilution effect. The measured concentrations of $\mathrm{Cd}$, $\mathrm{Co}, \mathrm{Cr}, \mathrm{Ni}$, and $\mathrm{Pb}$ were recorded higher than water quality guidelines. PCA and CA indicated that both geogenic and anthropogenic activities were contributing factors to metal abundance in the Lake. Cluster analysis grouped all sampling sites into three major clusters. Higher concentrations of metals were found near urban areas revealing that their concentrations had been strongly affected by anthropogenic influences. Thus, it was logical to conclude that the elevated concentrations of metals in Lake water were considerably due to direct discharge of untreated municipal/industrial wastes into the Lake. Human health risk was assessed using exposure risk assessment model which indicated $\mathrm{Cd}, \mathrm{Co}, \mathrm{Cr}, \mathrm{Ni}$, and $\mathrm{Pb}$ were the most prevalent pollutants causing noncarcinogenic concerns in all seasons and the oral ingestion was the major exposure pathway. Therefore, special attention should be paid to manage $\mathrm{Cd}, \mathrm{Co}, \mathrm{Cr}, \mathrm{Ni}$, and $\mathrm{Pb}$ in the study area and measures needed to be taken for sustaining the healthy aquatic ecosystem.

\section{Conflict of Interests}

The authors declare that there is no conflict of interests regarding the publication of this paper.

\section{Acknowledgments}

The research fellowship awarded by the Higher Education Commission (HEC), Pakistan, and Quaid-i-Azam University, Islamabad, Pakistan, to carry out this project is thankfully acknowledged. The authors are also grateful to the administration of Mangla Lake, Pakistan, for their assistance and help during the sampling campaigns.

\section{References}

[1] G. Forghani, F. Moore, S. Lee, and A. Qishlaqi, "Geochemistry and speciation of metals in sediments of the maharlu saline lake, shiraz, sw iran," Environmental Earth Sciences, vol. 59, no. 1, pp. 173-184, 2009.

[2] D. Hou, J. He, C. Lü et al., "Distribution characteristics and potential ecological risk assessment of heavy metals $(\mathrm{Cu}, \mathrm{Pb}$, $\mathrm{Zn}, \mathrm{Cd}$ ) in water and sediments from Lake Dalinouer, China," Ecotoxicology and Environmental Safety, vol. 93, pp. 135-144, 2013.

[3] Y. Hu, S. H. Qi, C. X. Wu et al., "Preliminary assessment of heavy metal contamination in surface water and sediments from Honghu Lake, East Central China," Frontiers of Earth Science, vol. 6, no. 1, pp. 39-47, 2012.

[4] M. Varol, "Dissolved heavy metal concentrations of the Kralkızı, dicle and batman dam reservoirs in the tigris river basin, turkey," Chemosphere, vol. 93, no. 6, pp. 954-962, 2013.

[5] A. K. Krishna, M. Satyanarayanan, and P. K. Govil, "Assessment of heavy metal pollution in water using multivariate statistical techniques in an industrial area: a case study from Patancheru, Medak District, Andhra Pradesh, India," Journal of Hazardous Materials, vol. 167, no. 1-3, pp. 366-373, 2009.

[6] S. Li and Q. Zhang, "Spatial characterization of dissolved trace elements and heavy metals in the upper Han River (China) using multivariate statistical techniques," Journal of Hazardous Materials, vol. 176, no. 1-3, pp. 579-588, 2010.

[7] S. Li, Z. Xu, X. Cheng, and Q. Zhang, "Dissolved trace elements and heavy metals in the Danjiangkou Reservoir, China," Environmental Geology, vol. 55, no. 5, pp. 977-983, 2008.

[8] H. Pekey, D. Karakaş, and M. Bakoglu, "Source apportionment of trace metals in surface waters of a polluted stream using multivariate statistical analyses," Marine Pollution Bulletin, vol. 49, no. 9-10, pp. 809-818, 2004.

[9] E. Pertsemli and D. Voutsa, "Distribution of heavy metals in Lakes Doirani and Kerkini, Northern Greece," Journal of Hazardous Materials, vol. 148, no. 3, pp. 529-537, 2007.

[10] H. Bem, M. Gallorini, E. Rizzio, and M. Krzemińska, "Comparative studies on the concentrations of some elements in the urban air particulate matter in Lodz City of Poland and in Milan, Italy," Environment International, vol. 29, no. 4, pp. $423-$ 428, 2003.

[11] A. Demirak, F. Yilmaz, A. Levent Tuna, and N. Ozdemir, "Heavy metals in water, sediment and tissues of Leuciscus cephalus from a stream in southwestern Turkey," Chemosphere, vol. 63, no. 9, pp. 1451-1458, 2006.

[12] S. Li and Q. Zhang, "Risk assessment and seasonal variations of dissolved trace elements and heavy metals in the Upper Han River, China," Journal of Hazardous Materials, vol. 181, no. 1-3, pp. 1051-1058, 2010.

[13] M. G. Macklin, P. A. Brewer, K. A. Hudson-Edwards et al., "A geomorphological approach to the management of rivers contaminated by metal mining," Geomorphology, vol. 79, no. 3-4, pp. 423-447, 2006.

[14] R. Reza and G. Singh, "Heavy metal contamination and its indexing approach for river water," International Journal of Environmental Science and Technology, vol. 7, no. 4, pp. 785-792, 2010.

[15] A. R. Karbassi, S. M. Monavari, G. R. Nabi Bidhendi, J. Nouri, and K. Nematpour, "Metal pollution assessment of sediment and water in the Shur River," Environmental Monitoring and Assessment, vol. 147, no. 1-3, pp. 107-116, 2008. 
[16] N. Malik, A. K. Biswas, T. A. Qureshi, K. Borana, and R. Virha, "Bioaccumulation of heavy metals in fish tissues of a freshwater lake of Bhopal," Environmental Monitoring and Assessment, vol. 160, no. 1-4, pp. 267-276, 2010.

[17] J. Nouri, A. H. Mahvi, G. R. Jahed, and A. A. Babaei, "Regional distribution pattern of groundwater heavy metals resulting from agricultural activities," Environmental Geology, vol. 55, no. 6, pp. 1337-1343, 2008.

[18] M. Varol and B. Şen, "Assessment of nutrient and heavy metal contamination in surface water and sediments of the upper Tigris River, Turkey," Catena, vol. 92, pp. 1-10, 2012.

[19] S. M. Sakan, D. S. Dordević, D. D. Manojlović, and P. S. Predrag, "Assessment of heavy metal pollutants accumulation in the Tisza river sediments," Journal of Environmental Management, vol. 90, no. 11, pp. 3382-3390, 2009.

[20] M. Varol, B. Gökot, A. Bekleyen, and B. Şen, "Water quality assessment and apportionment of pollution sources of Tigris River (Turkey) using multivariate statistical techniques-a case study," River Research and Applications, vol. 28, no. 9, pp. 14281438, 2012.

[21] M. C. Casado-Martínez, J. M. Forja, and T. A. DelValls, "A multivariate assessment of sediment contamination in dredged materials from Spanish ports," Journal of Hazardous Materials, vol. 163, no. 2-3, pp. 1353-1359, 2009.

[22] C.-Y. Chung, J.-J. Chen, C.-G. Lee, C.-Y. Chiu, W.-L. Lai, and S.W. Liao, "Integrated estuary management for diffused sediment pollution in Dapeng Bay and neighboring rivers (Taiwan)," Environmental Monitoring and Assessment, vol. 173, no. 1-4, pp. 499-517, 2011.

[23] W. Luo, T. Wang, Y. Lu et al., "Landscape ecology of the Guanting Reservoir, Beijing, China: multivariate and geostatistical analyses of metals in soils," Environmental Pollution, vol. 146, no. 2, pp. 567-576, 2007.

[24] D. R. Satapathy, P. R. Salve, and Y. B. Katpatal, "Spatial distribution of metals in ground/surface waters in the Chandrapur district (Central India) and their plausible sources," Environmental Geology, vol. 56, no. 7, pp. 1323-1352, 2009.

[25] J. Zhou, D. Ma, J. Pan, W. Nie, and K. Wu, "Application of multivariate statistical approach to identify heavy metal sources in sediment and waters: a case study in Yangzhong, China," Environmental Geology, vol. 54, no. 2, pp. 373-380, 2008.

[26] M. J. Butt, R. Mahmood, and A. Waqas, "Sediments deposition due to soil erosion in the watershed region of Mangla Dam," Environmental Monitoring and Assessment, vol. 181, no. 1-4, pp. 419-429, 2011.

[27] American Public Health Association, American Water Works Association, and Water Environment Federation, American Public Health Association, American Water Works Association and Water Environment Federation Standard Methods for the Examinations of Water and Wastewaters, American Public Health Association, American Water Works Association and Water Environment Federation, Washington, DC, USA, 19th edition, 1995.

[28] M. Radojevic and V. M. Bashkin, Practical Environmental Analysis, Royal Society of Chemistry, Cambridge, UK, 1999.

[29] M. H. Shah, J. Iqbal, N. Shaheen, N. Khan, M. A. Choudhary, and G. Akhter, "Assessment of background levels of trace metals in water and soil from a remote region of Himalaya," Environmental Monitoring and Assessment, vol. 184, no. 3, pp. 1243-1252, 2012.
[30] J. Iqbal and M. H. Shah, "Distribution, correlation and risk assessment of selected metals in urban soils from Islamabad, Pakistan," Journal of Hazardous Materials, vol. 192, no. 2, pp. 887-898, 2011.

[31] M. Varol and B. Şen, "Assessment of surface water quality using multivariate statistical techniques: a case study of Behrimaz Stream, Turkey," Environmental Monitoring and Assessment, vol. 159, no. 1-4, pp. 543-553, 2009.

[32] M. Varol, B. Gökot, A. Bekleyen, and B. Şen, "Spatial and temporal variations in surface water quality of the dam reservoirs in the Tigris River basin, Turkey," Catena, vol. 92, pp. 11-21, 2012.

[33] StatSoft Inc, STATISTICA for Windows, Computer Programme Manual, StatSoft Inc, Tulsa, Okla, USA, 1999.

[34] E. De Miguel, I. Iribarren, E. Chacón, A. Ordoñez, and S. Charlesworth, "Risk-based evaluation of the exposure of children to trace elements in playgrounds in Madrid (Spain)," Chemosphere, vol. 66, no. 3, pp. 505-513, 2007.

[35] USEPA, "Risk assessment guidance for superfund, vol.1, human health evaluation manual (part E, supplemental guidance for dermal risk assessment)," Final Report EPA/540/R/99/005, OSWER 9285.7-02EP PB99-963312, Office of Superfund Remediation and Technology Innovation, US Environmental Protection Agency, Washington, DC, USA, 2004.

[36] B. Wu, D. Y. Zhao, H. Y. Jia, Y. Zhang, X. X. Zhang, and S. P. Cheng, "Preliminary risk assessment of trace metal pollution in surface water from Yangtze River in Nanjing section, China," Bulletin of Environmental Contamination and Toxicology, vol. 82, no. 4, pp. 405-409, 2009.

[37] S. Giri and A. K. Singh, "Risk assessment, statistical source identification and seasonal fluctuation of dissolved metals in the Subarnarekha River, India," Journal of Hazardous Materials, vol. 265, pp. 305-314, 2014.

[38] F. Liang, S. Yang, and C. Sun, "Primary health risk analysis of metals in surface water of Taihu Lake, China," Bulletin of Environmental Contamination and Toxicology, vol. 87, no. 4, pp. 404408, 2011.

[39] USEPA, Risk Assessment Guidance for Superfund, Volume 1, Human Health Evaluation Manual (Part A), Report EPA/540/189/002, United States Environmental Protection Agency, Washington, DC, USA, 1989.

[40] S. Adams, R. Titus, K. Pietersen, G. Tredoux, and C. Harris, "Hydrochemical characteristics of aquifers near Sutherland in the Western Karoo, South Africa," Journal of Hydrology, vol. 241, no. 1-2, pp. 91-103, 2001.

[41] D. Bellos and T. Sawidis, "Chemical pollution monitoring of the River Pinios (Thessalia-Greece)," Journal of Environmental Management, vol. 76, no. 4, pp. 282-292, 2005.

[42] S. Tokalioglu, S. Kartal, and L. Elci, "Speciation and determination of heavy metals in lake waters by atomic absorption spectrometry after sorption on amberlite XAD-16 resin," Analytical Sciences, vol. 16, no. 11, pp. 1169-1174, 2000.

[43] M. Gomo and D. Vermeulen, "Investigation of hydrogeochemical processes in groundwater resources located in the vicinity of a mine process water dam," Journal of African Earth Sciences, vol. 86, pp. 119-128, 2013.

[44] D. Voutsa, E. Manoli, C. Samara, M. Sofoniou, and I. Stratis, "A study of surface water quality in Macedonia, Greece: speciation of nitrogen and phosphorus," Water, Air, and Soil Pollution, vol. 129, no. 1-4, pp. 13-32, 2001.

[45] WHO, Guidelines for Drinking-Water Quality: Vol. 1 Recommendations Incorporating 1st and 2nd Addenda, World Health Organization, Geneva, Switzerland, 3rd edition, 2008. 
[46] USEPA, "National primary drinking water regulations," EPA 816-F-09-004, Office of Water, US Environmental Protection Agency, Washington, DC, USA, 2009.

[47] PakEPA, National Standards for Drinking Water Quality, Ministry of Environment, Environmental Protection Agency (PakEPA), Government of Pakistan, Islamabad, Pakistan, 2008.

[48] C. A. J. Appelo and D. Postma, Chemical Analysis of Groundwater, Geochemistry, Groundwater and Pollution, Balkema, Rotterdam, The Netherlands, 1996.

[49] P. Avila-Pérez, M. Balcázar, G. Zarazúa-Ortega, I. BarcelóQuintal, and C. Díaz-Delgado, "Heavy metal concentrations in water and bottom sediments of a Mexican reservoir," Science of the Total Environment, vol. 234, no. 1-3, pp. 185-196, 1999.

[50] M. Olías, J. M. Nieto, A. M. Sarmiento, J. C. Cerón, and C. R. Cánovas, "Seasonal water quality variations in a river affected by acid mine drainage: the Odiel River (South West Spain)," Science of the Total Environment, vol. 333, no. 1-3, pp. 267-281, 2004.

[51] M. Vega, R. Pardo, E. Barrado, and L. Debán, "Assessment of seasonal and polluting effects on the quality of river water by exploratory data analysis," Water Research, vol. 32, no. 12, pp. 3581-3592, 1998.

[52] X. Jiang, W. Wang, S. Wang, B. Zhang, and J. Hu, "Initial identification of heavy metals contamination in Taihu Lake, a eutrophic lake in China," Journal of Environmental Sciences, vol. 24, no. 9, pp. 1539-1548, 2012.

[53] E. Z. Ochieng, J. O. Lalah, and S. O. Wandiga, "Water quality and trace metal distribution in a pristine lake in the Lake basin in Kenya," Bulletin of Environmental Contamination and Toxicology, vol. 80, no. 4, pp. 362-368, 2008.

[54] A. O. Oyewale and I. Musa, "Pollution assessment of the lower basin of Lakes Kainji/Jebba, Nigeria: heavy metal status of the waters, sediments and fishes," Environmental Geochemistry and Health, vol. 28, no. 3, pp. 273-281, 2006.

[55] A. Samecka-Cymerman and A. J. Kempers, "Concentrations of heavy metals and plant nutrients in water, sediments and aquatic macrophytes of anthropogenic lakes (former open cut brown coal mines) differing in stage of acidification," Science of the Total Environment, vol. 281, no. 1-3, pp. 87-98, 2001.

[56] A. Samecka-Cymerman and A. J. Kempers, "Toxic metals in aquatic plants surviving in surface water polluted by copper mining industry," Ecotoxicology and Environmental Safety, vol. 59, no. 1, pp. 64-69, 2004.

[57] M. Saleem, J. Iqbal, and M. H. Shah, "Dissolved concentrations, sources, and risk evaluation of selected metals in surface water from mangla lake, Pakistan," The Scientific World Journal, vol. 2014, Article ID 948396, 12 pages, 2014.

[58] J. Iqbal, M. H. Shah, and G. Akhter, "Characterization, source apportionment and health risk assessment of trace metals in freshwater Rawal Lake, Pakistan," Journal of Geochemical Exploration, vol. 125, pp. 94-101, 2013.

[59] J. Iqbal and M. H. Shah, "Health risk assessment of metals in surface water from Freshwater Source Lakes, Pakistan," Human and Ecological Risk Assessment, vol. 19, no. 6, pp. 1530-1543, 2013.

[60] M. B. Arain, T. G. Kazi, M. K. Jamali, N. Jalbani, H. I. Afridi, and A. Shah, "Total dissolved and bioavailable elements in water and sediment samples and their accumulation in Oreochromis mossambicus of polluted Manchar Lake," Chemosphere, vol. 70, no. 10, pp. 1845-1856, 2008.
[61] T. G. Kazi, M. B. Arain, M. K. Jamali et al., "Assessment of water quality of polluted lake using multivariate statistical techniques: a case study," Ecotoxicology and Environmental Safety, vol. 72, no. 2, pp. 301-309, 2009.

[62] The Quality of Water Intended to Human Consumption, Directive 1998/83/ EC, Official Journal L330/05.12.1998, European Community (EC), 1998.

[63] USEPA, National Recommended Water Quality Criteria, Office of Water, Office of Science and Technology, US Environmental Protection Agency, Washington, DC, USA, 2006.

[64] H. Z. Tian, L. Lu, K. Cheng et al., "Anthropogenic atmospheric nickel emissions and its distribution characteristics in China," Science of the Total Environment, vol. 417-418, pp. 148-157, 2012.

[65] K. S. Kasprzak, F. W. Sunderman Jr., and K. Salnikow, "Nickel carcinogenesis," Mutation Research-Fundamental and Molecular Mechanisms of Mutagenesis, vol. 533, no. 1-2, pp. 67-97, 2003.

[66] N. Arnich, V. Sirot, G. Rivière et al., "Dietary exposure to trace elements and health risk assessment in the 2nd French Total Diet Study," Food and Chemical Toxicology, vol. 50, no. 7, pp. 2432-2449, 2012.

[67] M. Tahri, F. Benyaïch, M. Bounakhla et al., "Multivariate analysis of heavy metal contents in soils, sediments and water in the region of Meknes (Central Morocco)," Environmental Monitoring and Assessment, vol. 102, no. 1-3, pp. 405-417, 2005.

[68] H. F. Kaiser, "The application of electronic computers to factor analysis," Educational and Psychological Measurement, vol. 20, pp. 141-151, 1960.

[69] M. Varol, "Assessment of heavy metal contamination in sediments of the Tigris River (Turkey) using pollution indices and multivariate statistical techniques," Journal of Hazardous Materials, vol. 195, pp. 355-364, 2011.

[70] Y. Dou, J. Li, J. Zhao, B. Hu, and S. Yang, "Distribution, enrichment and source of heavy metals in surface sediments of the eastern Beibu Bay, South China Sea," Marine Pollution Bulletin, vol. 67, no. 1-2, pp. 137-145, 2013.

[71] P. Xia, X. W. Meng, P. Yin, Z. M. Cao, and X. Q. Wang, "Eightyyear sedimentary record of heavy metal inputs in the intertidal sediments from the Nanliu River estuary, Beibu Gulf of South China Sea," Environmental Pollution, vol. 159, no. 1, pp. 92-99, 2011.

[72] H. Zhang and B. Shan, "Historical records of heavy metal accumulation in sediments and the relationship with agricultural intensification in the Yangtze-Huaihe region, China," Science of the Total Environment, vol. 399, no. 1-3, pp. 113-120, 2008. 

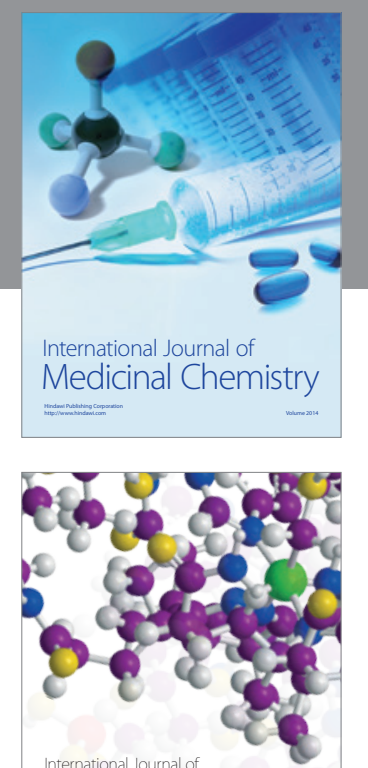

\section{Carbohydrate} Chemistry

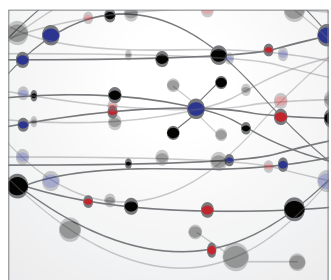

The Scientific World Journal
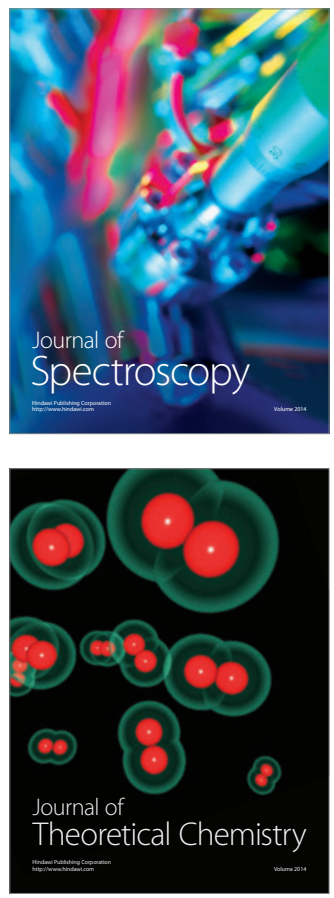
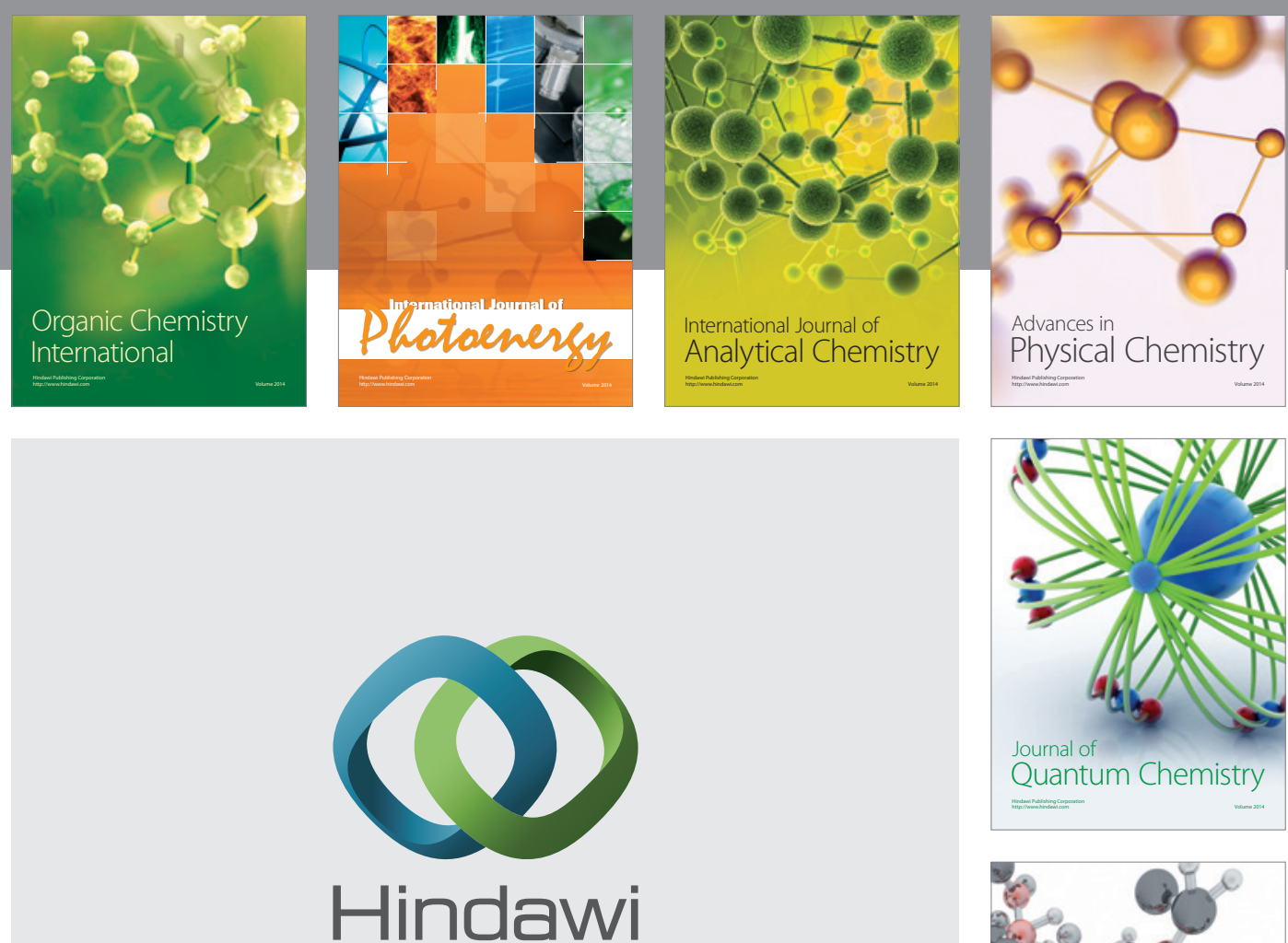

Submit your manuscripts at

http://www.hindawi.com

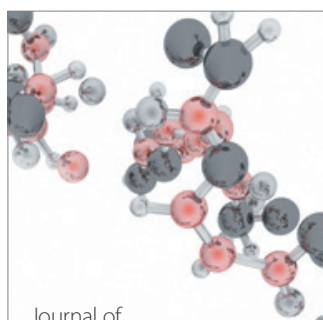

Analytical Methods

in Chemistry

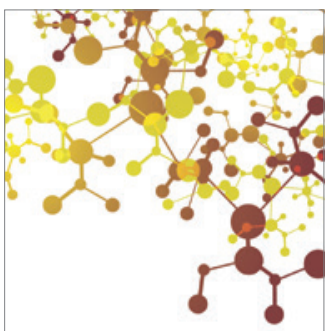

Journal of

Applied Chemistry

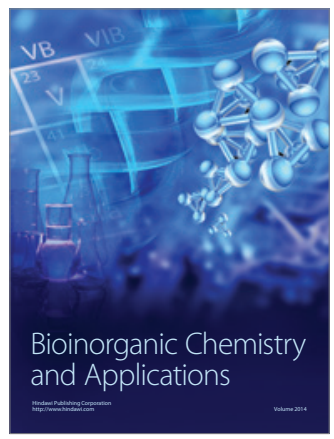

Inorganic Chemistry
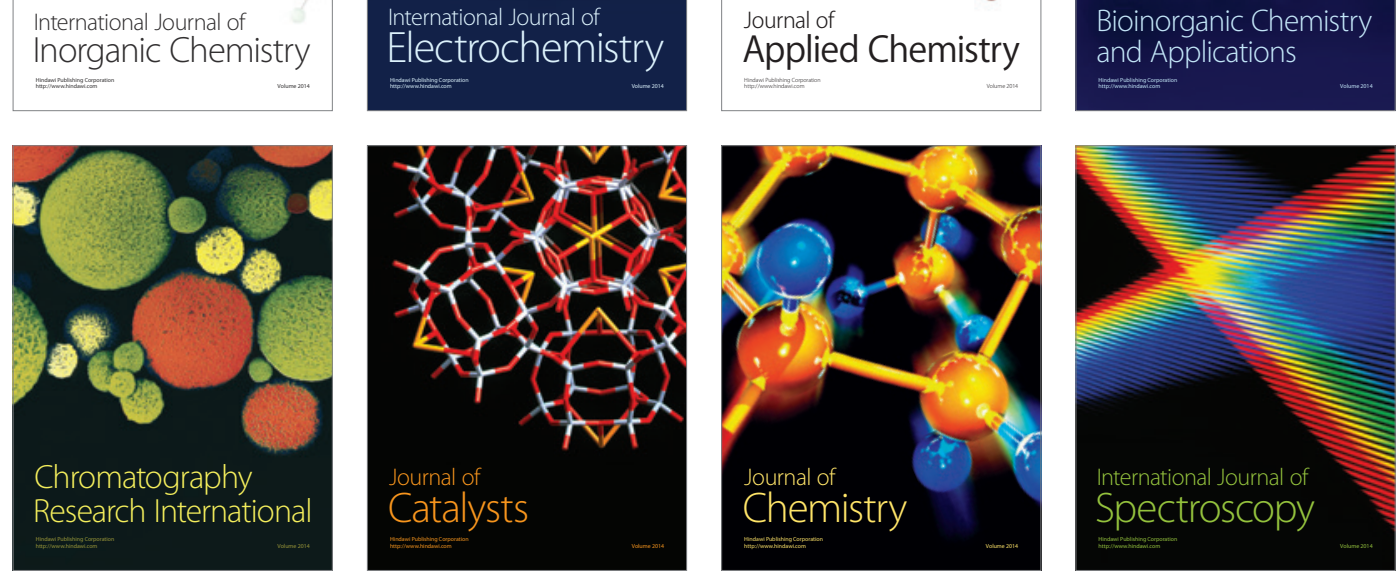